\title{
Contextual Factors in using E-Learning Systems for Higher Education in India
}

\author{
Rakesh H M \\ Assistant Professor Dept. of Business Administration Vidyavardhaka College of Engineering, Mysore
}

\begin{abstract}
The basic computing facilities are available in most of the Asian countries like India; however it is never possible to attain the same outputs from digital systems working either in public or private sector. There is emerging difference from the impacts of contextual factors which can make or break the objectives of a digital move in any sector including higher education. There are personal, organizational, and social contexts which are creating a particular type of culture or lifestyle of the inhabitants. If the contexts are in favor, it will result in the digital revolution happening in a spell of time but if context is either neutral or rival then the developers and users of E-Learning systems have to take account of all the possible influences emerging from any context while developing, implementing and using the new digital devices in a particular work environment. This paper tries to study the literature to uphold the arguments of E-Learning systems for higher education.
\end{abstract}

Keywords: Digital systems, E-Learning Systems, Higher Education

\section{Introduction}

Information and communication technologies (ICTs) have enormous potential in education however, the development, use and change management of eLearning happens with a particular context. The contextual factors influence the E-Learning theories and practices, which must be understood by the developers and users. The context is multifaceted which includes community, culture \& technology have become critical when understanding and implementing ICTs in education. The organization of higher education institution (HEI) is made of internal and external elements. Internal factors are the human characteristics and the organizational attributes and external context is made of government ICT-policies and the broader social environment.

The research tries to show the contextual factors either a support or obstacle in the process of ELearning development and use. System developers need to design an E-Learning model within the context of the existing support and resources. There will be no common E-Learning-model to fit every context rather learning has to be conducted within the culturally defined contextual frameworks. E-Learning is a multi-dimensional concept which needs to be comprehended in terms of its relationship with the social environment within which it is applied, meaning that a successful eLearning model in UK may not be as successful in India.

There are also several benefits emerging from E-Learning systems, difficulties occur when systems are not developed according to the learner characteristics such as nationality, gender, and cognitive learning style. Two primary variables are users" interest in eLearning and their competencies in using digital facilities (Lynch et al., 2005). The learner preferred-learning path depends on their personal characteristics of age, gender, teacher-led or self-study, familiarity with computer, and learning style. Likewise, teachers"e use ICTs which is influenced by a diversity of factors like: demographics; accessibility; digital literacy, perceived usefulness and ease of use of new system.

New generation students (Net Geners) are using media in many different formats, which shows a new learning style as is their multitasking: using computers and the Internet at the same time as video games, print media, music, and phone. The teachers, students and other users of ICTs will behave according to their demographic characteristics of age, educational level, cultural background, physical and learning disabilities, experience, personal objectives and attitudes, learning preferences and styles, motivation, reading/writing skills, ability to work with diverse cultures, familiarity with differing instructional methods and previous experience with E-Learning.

\section{E-Learning in Higher Education Institutes}

The increasing contextual impact on E-Learning is being identified in the research about the integration of educational technologies (Stephenson, 2006; Hameed, 2007). In traditional computer-based learning, the computer which was used as a tool to complete a task or get something done so there was no need to address the broader environmental context of the individual (Qureshi et al., 2009). In a study of Indian universities, found that "most IT education is ineffective because it is largely on technical grounds and not at all concerned with contexts and real world problems (Nawaz \&Kundi, 2010c). Another research on E-Learning reveals that despite the best of intentions, efforts and resources, many of the E-Learning projects end in failure because they won't undertake perspectives of existing and changing social and political context (Nawaz et al., 2011c). 


\section{Internal Context}

For E-Learning projects consideration must be given to the learning objectives and outcomes, the characteristics of the learners, and the learning context in order to leverage optimum E-Learning facilities (Tinio, 2002). 83 teachers from 29 Australia's universities recorded perceptions of the factors affecting their teaching work and then categorized internal context into individual and organizational domains, which interact with each other and the university environments (Lynch et al., 2005). Likewise, use of project management, instructional design, course development and all other academic and administrative techniques are crucial for a successful integration of technology in a broader institutional context (Nawaz \& Qureshi, 2010a; Nawaz, 2013a).

\section{User-Characteristics \\ a. Perceptions about ICTs}

To assess an individual's approach to computer use by testing an individual attitude to these technologies because numerous studies have explored individual differences in attitudes towards computers (Bataineh\& Abdel-Rahman, 2006). Understanding teachersperceptions of technology integration training and its impact on their instructional practice will help both the technology training programs and eLearning development process (Nawaz \&Kundi, 2010b). As teachers' attitudes are strongly related to their success in using technology, students ${ }^{\text {ee }}$ use of computer also depends on the perceived usefulness of these resources in terms of effective communication and access to information (Nawaz, 2011). It can be noted that very little research has been published about students' perceptions of their computer literacy, especially in developing countries.

\section{b. Approaches/Theories about the Role of ICTs}

The diversity of perceptions about the role of ICTs in Higher Education Institutes isgrouped into two broad theories of the E-Learning projects:

1. The instrumental approach: It is technological tool and possess no inherent value (neutral) and its value lies in how is it used thus, a universal model of learning is possible. Since education serving the society there should be more emphasis on the utility and relevance of education. The instrumental approach contains the risk of limiting students to their subjects/jobs and restraining them from critical thinking about broader social and communal issues (Nawaz \&Kundi, 2010c).

2. The substantive approach: The determinist theory of arguing that technology is not neutral rather has positive or negative implications for the individual, organization, and society. It postulates that just existence of technology will lead to familiar and standard applications, which in turn brings social change (Nawaz \& Qureshi, 2010b). The substantive theory matches the liberal theory of education, which considers learning is active, interconnected and socially collaborative experience and not merely a recollection of facts and figures (Nawaz \&Zubair, 2012b).

\section{c. Learning/Teaching Styles}

The generation X students has different learning styles: some learn fast while others are slow learners and tend to repeat; some prefer working alone while others like working in groups. ICTs is allowing personalization and customization of technologies according to the individual user styles. It is believed that learning style is a good predictor of an individual's learning behavior. It is an individual's inherited foundation, stemming from the past and depending on the demands of the present to emphasize on learning abilities over others (Nawaz \&Kundi, 2011). It is not possible for instructors to accommodate individual styles of each student therefore it is important to provide multiple learning opportunities because a match between learning and teaching style buildup students satisfaction (Nawaz \&Zubair, 2012c).

\section{d. User Types}

There can be several users of E-Learning facilities offered by the Institutions; however, those which are called university-constituents include teachers, students and administrators. Other researchers use the nomenclature of education-community and enlist teachers, administrators, district superintendents, legislators, etc. to represent the stakeholders of HEIs, who is held responsible for the development and use of educational technology (Buzhardt\&Heitzman-Powell, 2005). So the campus-constituents (Carey \& Gleason (2006) are the teachers, students and the administrative personnel (Nawaz, 2013a). 


\section{i) Teachers}

The challenging nature of Pedagogy demands greater preparedness by the teacherspossessing widerteaching techniques (Nawaz \& Qureshi, 2010b). A Teacher is considered as a mentor, coach or facilitator and expected to perform diverse functions in the eLearning environment particularly:

1. Managerial: The teacher plans the teaching program, which includes objectives, learning outcomes, timetable, rules and procedures, content development and establishment of the practical work and interactive activities.

2. Intellectual: It is the traditional teaching function in which teacher should know the syllabus and the particular subject which will inform the learning content.

3. Social: The fundamental function in E-Learning and E-Training that the teacher creates conducive learning environment, interacts with students and examines their feedback. To perform this function, the Teacher should motivate, facilitate and encourage the students in the new learning environments.

\section{ii) Students}

Contemporary Students are denoted by several concepts to express their involvement with ICTs: Computer Geeks/Nerds (Thomas \& Allen, 2006); Net-Generation, Net Genres, and Net-Savvy students (Barnes et al., 2007); Millennials, and Electronic Natives (Garcia \& Qin, 2007) and so on. Instead of learning from computers, students are able to learn with computers in the contemporary constructivist environments (Young, 2003). Given that most students can access various forms of IT - MP3, cell phones, PDAs (Aaron et al., 2004), it is obvious that the Net Generation is different from the previous generations in terms of their technological abilities, teamwork skills, and openness to participatory pedagogies (Garcia \& Qin, 2007).

\section{iii) Administrators/Staff}

The ICTs are successful in fostering logistics, administrative processes, distribution of materials and instructional communication (Valcke, 2004). It has more impact on administrative services (e.g. admissions, registration, fee payment, purchasing) than on the pedagogic practices in the classroom (Dalsgaard, 2006). In the same way ICTs are also facilitating organizational learning through improved forms of communication and sharing (Laffey\& Musser, 2006). The administration (or management) provides the original momentum for ELearning development and use because high-quality digital literacy and teaching requires the administration to provide moral and technical support for faculty (Ezziane, 2007).

\section{Organizational Characteristics}

The organizational policies, structures, authority and responsibility, rules of business, and on the top its culture, determines the destiny of any project including creation of E-Learning environments in a higher education institutes. In the E-Learning development and use practices, "the organizational context of ICTintegration is a major impediment (Sasseville, 2004)." Similarly, the perceptions, development and use of eLearning vary with the change in organizational context (Cawson, 2005).

The organizational domain, organizational support provided through allocation of resources and symbolic support reflected in an institution's systems, policies and processes are the critical success and failure factors (Lynch et al., 2005). Research shows that the execution of the digital opportunity initiatives will be linked closely to organizational changes (Nyvang, 2006). Therefore, to move the educational practices forward HEIs need to experiment with new organizational models to accommodate the contemporary digital requirements of the industry, market and society at large by providing state of the art and cutting-edge ICT graduates (Thompson, 2007; Nawaz, 2012a).

\section{External Context}

There is a conflict between the requirements of industry/market for graduates and whatever, is produced by the universities. ICT graduates are required to develop a cache of knowledge and skills (Ekstrom et al,. 2006) and studies report that the gap between theory and practice is widening and the computing-curricula is failing to reflect the external demands (Andriole, 2006). Due to the globalization and global-village, governments are facing problems in enabling their education system to transform the societies into information and knowledge-communities (Goddard \&Cornford, 2007). Modern organizations have requirement for technical talent to fill new digital job-profiles like network managers, web administrators, developers, programmers and security specialists, but universities seems to be in trouble, for example, student-enrollments in ICT-related courses are increasing all over the world but the output of IT graduates is still less than the demand (Ezziane, 2007). 


\section{Government Policies}

The teachers and students matters in E-Learning projects but government agencies control goal -setting, project-management, working conditions, evaluation, and the allocation of resource for projects particularly, in public sector HEIs (Aaron et al., 2004). The governments have established committees, taskforces and dedicating huge amounts of money for the enhancement of computer-based pedagogy (Abrami et al., 2006). Mathur (2006) states that the growth of a powerful Indian ICT industry is founded on the concerted efforts by the Government. E-Learning has clear implications for national, regional and local governments in terms of the need to establish policies and practices that enhance the capability of universities to perform new roles in the digital societies through state-of-the-art eLearning platforms (Goddard \&Cornford, 2007).

\section{Broader Social Context}

ICT not only brings about changes in the way to deal with information but also changes the way we think and how we view our world. Cultural change is bringing about a greater access to information and the fact that this access is provided by new technical means makes it more "scientific". This type of cultural change is creating a form of stress, fuelled by the inability of the individual to be in sync with the speed of cultural transformation; becoming an outcast in the information society which is presented as the ultimate fear (Sasseville, 2004). Many factors in education is complicating the process of innovation: Technological, social and pressures from the work world encourage educational institutions to evolve. Domain that readily accepts change, education reacts gradually to these external pressures (Zubair et al., 2013).

Today's world's culture is no longer only literary and art, but also it should be enabled by technology and science. ICT is at the crossroads of these two aspects. Refusing the condemning illiteracy and being unable to integrate into today's world (Sasseville, 2004). The integration of ICTs in HEIs demands a re-definition and re-evaluation of role in education and development of society according to thechanging social context, where the communication networks are radically changing and knowledge is becoming the central driving force (Loing, 2005) verifying that "learning cannot be separated from its social context (Ward et al., 2006)." The teachers of modern age are constantly forced by media, education-department, professional associations, and parents to update. The social grounds for an E-Learning in HEI cannot be neglected in a serious undertaking.

\section{Major Contextual Issues}

\section{Contextual Factors from Diversity}

Context is either a support or a barrier for E-Learning. There are a number of challenges that are faced by universities in developing countries as they seek to implement the e-learning systems. In developing countries the results are almost similar to developed states in many terms as well as different at broader level (Nawaz \&Kundi, 2010a). Despite research and testimony that technology is being used by more faculty, the diffusion of technological innovations for teaching and learning has not been widespread, nor it has become deeply integrated into the curriculum based learning. Given that E-Learning solutions must be compatible with the contextual factors of any country, the measurement and assessment of demographic impacts on user perceptions are critical to the successful digital opportunity initiatives for higher education in a developing country (Nawaz \&Kundi, 2010c).

\section{Mindset Problems}

The surveys on use of new age technology teaching are partly intimidating. A large target population finds it easier to prepare lectures on transparencies rather than use the computer. In some cases integrating technology into the teaching-learning transaction has been found to transform the teacher's role from being the traditional sage on the stage to also being a "guide on the side", and student roles also change from being passive receivers of content to being more active participants and partners in the learning process (Mehra\&Mital, 2007). Researchers have been doing constantly to identify the incompatibility of the eLearning models with the contextual requirements of the countries particularly, in the developing world (Nawaz \&Kundi, 2010b; Nawaz, 2013).

Teachers are reluctant to integrate technological innovations into their daily scholarly activities and this situation has not really changed over the past few years (Sasseville, 2004). There is a difference in perceptions and attitudes of eLearning-users, with those who dislike information and communication technologies (ICTs) on one extreme and those who are their promoters on the other end while many groups can be located at different points between the two extremes. There is a different kind as well as difference of degree between the conceptions and behavior of users about the nature and role of ICTs in higher education. The research reveals that these differences of attitudes is from the contextual factors relating to individual, group and organizational characteristics (Nawaz \&Kundi, 2010a). 


\section{Mismanagement of eLearning Systems}

The applications of information technology in classrooms validate that technology-based models of teaching and learning have the power to dramatically improve educational outcomes. But, classroom computers that are acquired as panaceas end up as doorstops (Mehra\&Mital, 2007). Unless other simultaneous innovations in pedagogy, curriculum, assessment, and school organization are coupled to the usage of instructional technology, the time and effort expended on implementing these devices produces improvements in educational outcomes - and reinforces many educators"e (Nawaz, 2013a).

\section{Conclusion}

The research have explored the educational cultures that can pass through different phases of maturity regarding change, ready to move forward, backward, or maybe not at all. It is quite common evident from the publications those teachers are adapting their practice to the use of information technology but only to a certain extent. They are not willing to throw away years of precious experience simply to adopt a tool that is generally perceived as ill-fitted to the framework of their craft.

Teachers are refusing the popular conception of professional merit by technological means. They doesn't want their competence as educational professionals evaluated merely by their ability to use the technology in the classroom. The patterns of the implementation activity that all involved return to over and over again are identification of needs for development with ICT, choice of ICT and development of practice with ICT.

There is no doubt in the fact that ICT is not neutral rather supported by an ideological complexity that represents ideas as diverse as the globalization of the economy, information society and the end of national policy in the favor of world government. A number of communities interest in and perspectives on the relationship between people and ICTs. It includes industry, academia, designers, policy makers and other institutions. Instructors are feeling that they have pressure to use IT, but they commonly face several obstacles when attempting to use technological teaching techniques. Institutions of higher education must strategically develop IT integration plans that help overcome these obstacles, addressing the needs of diverse pedagogical agendas and multiple levels of comfort with technology.

There needs to be a focus on the bottle necks in the way of successful and context-friendly E-Learning systems because barriers can make technology use frustrating for the technologically perceptive, let many teachers who may be somewhat techno-phobic. The digital literacy of teachers is indispensible otherwise one cannot expect teachers to play their due roles in the movement of computer literacy by making their students to so develop their culture and context that their life becomes digitally charged work environments and broader contexts.

\section{References}

[1]. Aaron, M., Dicks, D., Ives, C. \& Montgomery, B. (2004). Planning for Integrating Teaching Technologies.Canadian Journal of Learning and Technology, 30(2), Spring. Retrieved May 14, 2007, from http://www.cjlt.ca/.

[2]. Abrami, P. C., Bernard, R. M., Wade, A., Schmid, R. F., Borokhovski, E., Tamim, R., Surkes, M. A., Lowerison, G., Zhang, D., Nicolaidou, I., Newman, S., Wozney, 1., and Peretiatkowicz, A. (2006). A Review of e-Learning in Canada: A Rough Sketch of the Evidence, Gaps and Promising Directions. Canadian Journal of Learning and Technology, 32(3), Fall/Autumn.Retrieved May 14, 2007, from http://www.cjlt.ca/.

[3]. Ågerfalk, P. J., Goldkuhl, G., Fitzgerald, B., \&Bannon, L. (2006). Reflecting on action in language, organizations and information systems.European Journal of Information Systems, 15, 4-8. Retrieved May 11, 2007, from http://www.palgrave-journals.com/ejis/.

[4]. Andriole, S. J. (2006). Business Technology Education in the Early 21st Century: The Ongoing Quest for Relevance. Journal of Information Technology Education, 5.Retrieved July 14, 2007, from http://jite.org/documents/Vol5/.

[5]. Barnes, K., Marateo, R. C., \& Ferris, S. P. (2007). Teaching and Learning with the Net Generation. Innovate Journal of Online Education, 3(4). Retrieved April 10, 2007, from http://Innovateonline.info/.

[6]. Carey, P. \& Gleason, B. (2006). Vision 2010: The Future of Higher Education Business and Learning Applications. Innovate Journal of Online Education, 3(1). Oct/Nov. Retrieved April 10, 2007, from http://Innovateonline.info.

[7]. Cawson, P. A. (2005). ICTs in Teacher Education: What do teachers need to learn? International Conference on Teacher Education, "Quality Teacher Education: The Challenges of the 21st Century" University of Cape Coast, Ghana, 17-20 August 2005. Retrieved April 19, 2007, from http://www.fiankoma.org/pdf/ICTs\%20in\%20Teacher\%20Education.pdf

[8]. Dalsgaard, C. (2006). Social software: E-learning beyond learning management systems. European Journal of Open, Distance and E-Learning.Retrieved April 10, 2007, from http://www.eurodl.org/.

[9]. Drucker, M. J. (2006). Commentary: Crossing the digital divide: How race, class, and culture matter. Contemporary Issues in Technology and Teacher Education, 6(1).Retrieved July $18, \quad 2007$ from http://www.citejournal.org/vol6/iss1/languagearts/article2.cfm.

[10]. Juniu, S. (2005). Digital Democracy in Higher Education Bridging the Digital Divide.Innovate Journal of Online Education, 2(1), October/November. Retrieved April 10, 2007, from http://Innovateonline.info.

[11]. Knight, C., Knight, B. A. \&Teghe, D. (2006). Releasing the pedagogical power of information and communication technology for learners: A case study.International Journal of Education and Development using ICT, 2(2). Retrieved May 11, 2007, from http://ijedict.dec.uwi.edu//. 